\title{
Finansal Raporlama Standartları'nın Piyasa Değerini Açıklama Gücü Üzerine Etkisi: Borsa İstanbul Uygulaması
}

Umut UYAR *

\section{ÖZET}

Günümüzde hızlı ve kolay sağlanan bilginin güvenilirliği ile birlikte kolay anlaşıllı olması da her zaman tartışma konusu olmaktadır. Bilginin güvenilir olması garanti altına alınsa da, farklı ülkelerin farklı finansal sistemlere sahip olması anlaşılırlık konusunda sorunlar oluşturabilmektedir. 2001 yılında kurulmuş olan Uluslararası Muhasebe Standartları Kurulu (IASB) dünya ülkelerini aynı muhasebe ve finansal raporlama standartlarına bütünleştirerek, ekonomik sinırların ortadan kaktığ finansal piyasalar oluşturmayı hedeflemektedir. Bu hedef doğrultusunda 2005 yllından itibaren Türkiye'de, halka açı şirketlerde, Türkiye Muhasebe Standartları (TMS) / Türkiye Finansal Raporlama Standartları (TFRS) adları altında uluslararası standartların çevirileri kullanılmaktadır. Bu çalışmanın amacı, Türkiye'de TMS/TFRS uygulamalarının halka açık şirketlerin piyasa değerleri üzerindeki açıklama gücünü yerel mevzuat ile karşılaştırarak analiz etmektir. 2000-2004 ve 20052009 dönemlerinde Borsa İstanbul'da faaliyet gösteren 225 firmanın dahil edildiği çalışmada, panel veri analizi kullanılmıştır. Sonuç olarak, TMS/TFRS uygulamalarına göre hazırlanan mali tabloların yatırımcilar tarafindan daha güvenilir kabul edildiği ve 2005 yılı sonrasında, öncesine göre fiyatlamayı daha yüksek ölçüde açıkladı̆̆ı sonucuna ulaşılmıştır.

Anahtar Kelimeler: UFRS, Piyasa Değeri Etkisi, Yerel Muhasebe Standartları, Sermaye Piyasaları, Panel Veri Analizi

JEL Sinıflandırması: D53, F30, M41

\section{The Impact Of Financial Reporting Standards On Explanatory Power Of Market Value: An Emprical Study On Borsa Istanbul \\ ABSTRACT}

Nowadays, information which could be found rapidly has a reliability and stability problem. Although a set of institutions guarantee the reliability and stability of information, investors still have problems about them. International Accounting Standards Board was founded in 2001 and its aim is developing quality, easily understandable, generally accepted and globally accounting information for investors. Correspondingly, the Turkey Accounting Standards / Turkey Financial Reporting Standards have been applied on Turkish firms which are trading in Borsa Istanbul Stock Exchange since 2005. The aim of study is that testing the impact of IFRS on publicly traded corporations' market value by comparing Turkish GAAP. Dataset includes 2000-2004 and 2005-2009 periods annually data of 225 publicly traded corporations' financial reports and panel data method was used for analysis. In conclusion, according to the investors, the financial reports which prepared with IFRS are more reliable than the financial reports which prepared with Turkish GAAP.

Keywords: IFRS, Impact of Market Value, Turkish GAAP, Capital Markets, Panel Data Method.

Jel Classification: D53, F30, M41

\footnotetext{
*Yrd. Doç. Dr., Pamukkale Üniversitesi, İşletme Bölümü, Muhasebe ve Finansman, uuyar@pau.edu.tr
} 


\section{GİRiş}

Gelişen teknoloji, bilginin hızlı ve sınırsız bir biçimde bireyler arasında aktarılmasını sağlamaktadır. Bilginin bu denli hızlı hareketi birçok avantaj sağlamanın yanında bir takım dezavantajlar da getirmektedir. Yatırımcılar açısından ülkeler arası yatırım firsatları edinmek, okyanus aşırı ülkelerde faaliyet gösteren firmalar hakkında finansal bilgilere sahip olmak bu teknolojik gelişmelerin muhasebe ve finans alanına en önemli katkılarından birini oluşturmaktadır. Diğer yandan, bu hızlı ve kolay sağlanan bilginin güvenilirliği ile birlikte kolay anlaşılır olması de her zaman tartışma konusu olmaktadır. Bir takım kurumlar tarafından bilginin güvenilir olması garanti altına alınsa da, yatıımcılar anlaşılırlığı konusunda sorunlar yaşamaktadır. Bunun nedeni, farklı ülkelerin farklı ticari geleneklere ve finansal sistemlere sahip olmasından kaynaklanmaktadır. Uluslararası Muhasebe Standartları Kurulu (IASB), 2001 yılında kurulmuş, bağımsız, kar amacı gütmeyen ve bu konuda faaliyet gösteren bir kurum olarak devreye girmektedir. IASB'nin temel amacı kaliteli, anlaşılır, genel kabul görmüş ve küresel muhasebe bilgisinin oluşturulmasını sağlamak olarak belirtilmektedir. Uluslararası Finansal Raporlama Standartları'nın (UFRS) hazırlanmas1, yayınlanması ve güncellenmesinden sorumlu olan IASB, temel amacı doğrultusunda tüm dünya ülkelerini aynı muhasebe ve finansal raporlama standartlarına bütünleştirerek, küreselleşme etkisi ile ekonomik sınırların ortadan kalktığı finansal piyasalarda muhasebe bilgisinin de kaliteli, anlaşılır ve küresel hale getirilmesine çalışmaktadır.

2005 yılından itibaren Türkiye'de halka açık şirketlerde, Türkiye Muhasebe Standartları (TMS) / Türkiye Finansal Raporlama Standartları (TFRS) adları altında Uluslararası Standartların çevirileri kullanılmaktadır. Bu standartlar Türkiye'de faaliyet gösteren halka açı şirketlerin gerek muhasebe uygulamalarında gerekse finansal raporlamalarında değişikliklere yol açmıştır. Uluslararası Standartlara uyum konusunda Türkiye'de uzun zamandır çalışmalar yapılmakla birlikte günümüzde muhasebe standartlarını oluşturma sorumluluğu Kamu Gözetimi, Muhasebe ve Denetim Standartları Kurumu (KGK)'ndadır. KGK'nın kuruluş amacı, yatırımcıların çıkarlarını ve denetim raporlarının doğru ve bağımsız olarak hazırlanmasına ilişkin kamu yararını korumak ile doğru, güvenilir ve karşılaştırılabilir finansal bilginin sunumunu sağlamak şeklinde belirtilmektedir. KGK, Denetim standartlarına göre bağımsız denetim faaliyetlerini gerçekleştirmenin yanı sıra bu standartların Türkçe 'ye çevrilmesi, uyumlaştırılması ve yayınlanması işlemlerinin de tek odağı olan kurumdur.

Türkçe çevirisi ve uyumlaştırılması yapılmış olan TMS/TFRS'ler ticari/finansal nitelikteki işlemlerin kayıt altına alınması, sınıflandırılması ve raporlanması aşamalarında önemli değişiklikler içermektedir. Standartların getirdiği değişikliklerin temel noktası, kaliteli, anlaşılır, küresel bilginin oluşturulmasının yanı sıra şirketlerin gerçek finansal durumlarının ilgili taraflara (yatırımcılar, paydaşlar, devlet, vs.) sunulması olarak vurgulanmaktadır. $\mathrm{Bu}$ araştırmanın amacı tam olarak bu noktada, Türkiye'de TMS/TFRS uygulamalarının halka açı şirketlerin piyasa değerleri üzerindeki açıklama gücünün yerel 
mevzuatı ifade eden Muhasebe Uygulamaları Genel Tebliği (MSUGT) ile karşılaştırarak analiz etmektir. Test edilmek istenen hipotez IASB 'nin standartların oluşturulmasındaki temel hedefi olan kaliteli, anlaşılır, genel kabul görmüş ve küresel muhasebe bilgisinin Türkiye piyasasında oluşup oluşmadığının araştırılmasıdır. TMS/TFRS ile oluşturulan finansal tabloların yatırımcı tarafından daha kaliteli ve doğru kabul edilmesinin şirketlerin piyasa değerlerine yansımış olması beklentisi çalışmanın temel varsayımıdır. Analizler sonucunda, TMS/TFRS uygulamalarının Borsa İstanbul'da (BİST) faaliyet gösteren halka açık şirketlerin piyasa değerlerini açıklama gücü, MSUGT uygulamalarına göre daha yüksek çıkması durumunda, IASB amaçlarının Türkiye piyasasında oluştuğunu göstermektedir.

Çalışmanın ilerleyen bölümlerinde ilk olarak uluslararası literatürde konu ile ilgili yapılmış benzer çalışmalar değerlendirilmektedir. İkinci bölümde, araştırma amacına uygun olarak kullanılacak metodoloji ve veri ile ilgili bilgilere yer verilmektedir. Son bölümde ise, bulguların yorumu ve sonuçların değerlendirmesi yer almaktadır.

\section{LITERATÜR INCELEMESİ}

Uluslararası Muhasebe Standartları Kurulu'nun (IASB) yirmi yılı aşkın bir süredir sürdürmekte olduğu çalışmaları şüphesiz birçok araştırmacı için çalışma alanını oluşturmaktadır. IASB 'nin, kaliteli, anlaşılır, genel kabul görmüş ve küresel muhasebe bilgisinin oluşturulmasını sağlama gayesinin geçerliliğinin test edilmesi, sürdürülen standart uyumlaştırması sürecinin önemli bir aşamasıdır. Bu konuda bağımsız araştırmacılar tarafından yapılmış ve literatürde yer alan oldukça çeşitli çalışmalar bulunmaktadır.

Konuya finansal tablo ile firma piyasa değeri ilişkisi üzerine yapılmış çalışmalar açısından bakılacak olursa; ilişski tespiti için yapılmış çalışmaları iki ana bölüme ayırmak mümkündür. Birincisi, finansal tablolarında hileli işleme başvurmuş firmaların tespitidir. Oluşturulan modellemeler ile firmaların piyasa değerleri ve finansal tablo verileri arasındaki ilişkinin kuvvet derecesi ölçüsünde doğruluğu sorgulanmaktadır. Çalışmanın odak noktası ile alakalı olmaması nedeni ile bu konudaki literatür dikkate alınmamıştır. İkincisi ise, firmaların Uluslararası Finansal Raporlama Standartları'na (UFRS) göre açıkladıkları finansal tablo bilgilerinin değer üzerindeki etsinin ne ölçüde olduğunu araştırmaktadır. Bu kategoride yer alan çalışmaları araştırma yöntemi açısından "Kalitatif Yöntem Araştırmaları" ve "Kantitatif Yöntem Araştırmaları" olarak iki ana başlıkta incelenmesi uygun karşılanmaktadır (Callao vd. 2007).

Kalitatif yöntem araştırmaları, UFRS uygulamalarına tam anlamıyla başlanmadan önceki veya geçiş dönemindeki çalışmalar ve genellikle araştırma yöntemi olarak anket ve finansal tabloların kalitatif yöntemlerle incelenmesini benimsemiş çalışmalardan oluşmaktadır. UFRS adaptasyonuna karşılık firmaların takındıkları tutumları incelemeye odaklanmaktadır. Bu çalışmalar, genellikle UFRS geçişi öncesi bilgi toplama ve genel görüş belirlemeye çalışmakta; ayrıca sonradan geçiş konusunda en toplu örneklemi oluşturması açısından genellikle Avrupa ülkelerini kapsamaktadır. UFRS geçişi öncesi yapılan bu 
çalışmaların çoğunda yöneticilerin olumsuz ve karşıı görüşleri yer almaktadır. Belçika piyasasındaki UFRS adaptasyonunu araştıran Jermakowicz (2004), BEL-20 endeksinde yer alan halka açık firmaların örgüt organizasyonu, muhasebe ve finans stratejileri açısından UFRS 'den ne kadar etkilendikleri üzerinde durmaktadır. Yazar, incelenen firmaların URFS ile birlikte örgüt içi ve dışı raporlama sistemlerinde kayda değer değişiklikler meydana geldiği sonucuna ulaşmıştır. Ormrod ve Taylor (2004), İngiltere piyasasında, firmaların UFRS sonrası borç senetleri konusunda nasıl etkilendiğini incelemiş ve bilanço kalemlerinde ve dönem karında değişikliklerin yanı sıra, gelir kalemlerinde de dalgalanmalar tespit etmiştir. Weißenberger vd. (2004), çalışmalarında Alman firmalarının Alman yerel mevzuatında kalma ya da UFRS 'ye geçiş gönüllülükleri araştırmıştır. Çalışmada, bilgi kaynaklarının gelişmesi ve uluslararası standartlaşma nedeniyle, Alman sermaye piyasalarında UFRS'ye geçişin giderek destek kazandığı sonucuna varılmıştır. Larson ve Street (2004), çalışmalarında Avrupa Birliği'ne üye ve aday statüde olan 17 Avrupa ülkesinin UFRS 'ye geçiş aşamasındaki süreçlerini incelemiş ve halka açık firmaların UFRS 'ye, halka açık olmayan firmaların ise yerel mevzuata göre raporlama yapmasının finansal sistemlerde ciddi karmaşalara yol açtı̆ı ortaya koymuşlardır. Almanya, Fransa ve İtalya'nın UFRS adaptasyonunun karşılaştıran Delvaille vd. (2005) ise, üç ülkenin ortak Avrupa sistemindeki ve UFRS geçişindeki aşamalarını ve sonuçlarını değerlendirmiş, tüm ülkelerin UFRS geçişi konusunda tamamen farklı yollar izlenildiği tespit etmişlerdir. Jermakowicz ve Gornik-Tomaszewski (2006), UFRS geçişi ardından Avrupa Birliği ülkelerini kapsayan bir çalışma gerçekleştirmiştir. Çalışma kapsamında oluşturulan anketi 112 Avrupa Birliği’nde faaliyet gösteren firma cevaplamış ve sonuç olarak firma yöneticileri geçiş sürecini maliyetli, karmaşık ve yıpratıcı bulduklarını ifade etmişlerdir. Avrupa dışından bir örnek çalışma olan Goodwin vd. (2008), 1065 halka açık Avusturalya firmasını analiz etmişlerdir. UFRS ile raporlama sonucunda yerel mevzuata göre tüm firmalarda toplam yabancı kaynaklarda artış, özkaynaklarda düşüş gözlenirken; dönem karı rakamları açısından bazı firmalarda artış, bazılarında düşüş̧ gözlenmiştir. Navarro-García ve Bastida (2010), İspanya'da faaliyet gösteren 63 firmalarda çalışan yöneticiler için UFRS adaptasyonunun etkileri üzerine bir anket çalışması yapmışlar ve yöneticilerin çoğunun UFRS adaptasyonu fayda maliyet analizi açısından başarısızlıklar içerdiğini düşündükleri sonucuna ulaşmışlardır.

İkinci grup çalışmalar olarak değerlendirilebilen kantitatif yöntem araştırmaları, daha çok finansal tablo bilgileri ile piyasada değeri ilişkisini ele alarak ekonometrik modelleme yapan çalışmaları kapsamaktadır. Bu çalışmalarda genel olarak, UFRS uygulamasına geçmiş ve bir süredir uygulamakta olan ülkelerdeki halka açı firma verileri kullanılarak yapılan analizler yer almaktadır. Genel olarak çalışmaların amacı, konunun başında da belirtildiği gibi, IASB 'nin kaliteli, anlaşılır, genel kabul görmüş ve küresel muhasebe bilgisinin oluşturulmasını sağlama gayesinin geçerliliğinin test edilmesi olarak ifade edilebilmektedir. Araştırmalardan elde edilen sonuçlara dikkat edildiğinde üç ayrı çıkarım ile karşılaşılmaktadır: Birincisi UFRS lehine finansal veri piyasa değeri ilişkisi tespit eden 
çalışmalar olurken, ikinci çıkarım, yerel mevzuat ve UFRS ile raporlamada herhangi istatistiksel olarak anlamlı bir farklılık belirlenemeyen çalışmalardır. Son olarak UFRS aleyhine finansal veri piyasa değeri ilişkisi tespit eden çalışmalar bulunmaktadır.

UFRS lehine sonuç elde edilen çalışmalarda da ortak bir takım çıkarımlar bulunmaktadır. Birinci ve en başta gelen çıkarım, IASB 'nin amaçladığı kaliteli, anlaşılır, genel kabul görmüş ve küresel muhasebe bilgisinin oluşturulması noktasında atılan adımların ve oluşturulan standartların işlediği yönündedir. Yazarlar genel olarak, UFRS 'nin yatırımcılara, firmaları daha net, açık ve şeffaf şekilde inceleme imkanı sağladığı görüşünü taşımaktadır. Bunun bir sonucu olarak URFS kapsamında oluşturulan finansal verilerin, firmaların piyasa değerleri ya da başka bir deyişle hisse senedi fiyatlarını açıklama gücü arttırdığı vurgulanmaktadır. Yazarların vurguladıkları diğer bir çıkarım, her ülke piyasasının karakteristik özellikleri bulunmasına rağmen standartlara olumlu cevap vermiş olmasıdır. Ancak UFRS lehine sonuca ulaşan çalışmalar geçiş sonrası standardizasyonun işlediğini göstermektedir. Geçmiş çalışmalardaki son çıkarım ise, UFRS 'nin gerek raporlamada gerekse uygulama aşamasında içerdiği köklü değişikliklerin zaten olması gereken muhasebe ve finans sistemini oluşturduğu görüşüdür. Bu noktaya vurgu yapan yazarlar, olması gereken uygulamaların hayata geçirilmesi ile firma değeri finansal veri ilişkisinin doğrudan etkilendiğini ve yükseldiğini belirtmektedir. Bu çıkarımda, yatırımcı algılarının da etkili olduğu belirtilmekle birlikte, firmaların gerçek durumlarının finansal verilere yansımasının hızlandırıcı nitelik taşıdığı vurgulanmaktadır. Harris ve Muller (1999) tarafından Amerika Birleşik Devletleri’nde (ABD) faaliyet gösteren 89 yabancı firma üzerinde Ohlson Modeli kullanarak yapılan çalışmada, UFRS düzeni içerisinde açıklanan finansal tablo verilerinin, ABD yerel mevzuatına göre hisse başına getiri üzerinde istatistiksel olarak daha ilişkili olduğu sonucuna ulaşı1mıştır. Bartov vd. (2005), Alman piyasasında gelirlerin firma piyasa değeri üzerine olan ilişkisini araştırmış ve UFRS 'nin Alman yerel mevzuatına göre firmaların piyasa değerleri ile daha fazla ilişkili olduğu sonucuna ulaşılmıştır. İngiltere açısından konuyu ele alan Horton ve Serafeim (2006) ise, Londra Borsası'ndan 2005 yılı için seçtikleri 85 firma ile araştırmalarını gerçekleştirmiştir. Analizlerinde piyasa modeli kullanan yazarlar, piyasa değeri finansal bilgi ilişkisinde UFRS'nin İngiltere yerel mevzuatına göre gelir rakamlarının oluşumunda daha ilişkili olduğunu ancak defter değeri rakamlarının ilişki açısından bir farklılık yaratmadığı sonucuna ulaşmışlardır. Schadewitz ve Vieru (2007) 'da çalışmasında Finlandiya piyasasında UFRS ve Fin yerel mevzuatı karşılaşıırması yapmışlar ve 2004 yılı içerisinde faaliyet gösteren halka açık firmaları dahil ettiği analizinde piyasa değeri finansal bilgi iliş̧kisinde Horton ve Serafeim (2006) ile aynı doğrultuda sonuçlara ulaşmışlardır. Beckman vd. (2007), Almanya'da finansal tablo verileri ve piyasa değeri ilişkisi üzerine yaptığı çalışmalarında, UFRS ile Alman yerel mevzuatı arasında piyasa değeri ilişkisi açısından sektörden sektöre değişen anlamlılıklar olduğu sonucuna ulaşmışlardır. Almanya'da yapılmış bir diğer çalışmada Hung ve Subramanyam (2007), 1998-2002 dönemi için Alman piyasasında UFRS ve Alman yerel mevzuatı arasındaki piyasa değeri ilişkisi farklılıkları 
üzerinde durmuşlardır. Çalışma sonucunda, UFRS ile yapılmış olan raporlamaların yerel mevzuata göre istatistiksel olarak çok daha fazla piyasa değeri ile ilişkili olduğu sonucuna ulaşmışlardır. Jermakowicz vd. (2007) yine Almanya DAX-30 'da işlem gören firmalar üzerine yaptıkları çalışmalarında 265 Alman firmasını 1995-2004 dönemleri için incelemiş ve Hung ve Subramanyam (2007) ile aynı doğrultuda sonuçlara ulaşmışlardır. Callao vd. (2007), İspanya'da IBEX-35'da faaliyet gösteren firmalar üzerine yaptıkları çalışmada, finansal tablo verileri yanında finansal oranlar konusunda da UFRS ile İspanya yerel mevzuatının piyasa değer ilişkisinde farklılıklarını incelemiş ve yerel mevzuat ile raporlamanın UFRS 'ye göre, oldukça kötü performans sergilediği sonucuna ulaşmışlardır. Christensen vd. (2007), araştırmalarında İngiltere piyasası üzerine bir vaka-çalışması tasarlamış ve UFRS 'ye geçiş noktasında İngiliz firma değerlerinin nasıl etkileneceğini analiz etmişıler ve İngiliz piyasasında gönüllü bir şekilde UFRS 'ye geçiş yaşanmasının firma değerleri üzerinde olumlu etkisi olabileceği sonucuna ulaşılmışlardır. Aygören (2007), çalışmasında 2004 yılı için Türkiye'de faaliyet gösteren halka açık 65 şirketin finansal tablo verilerini kullanmış ve yerel mevzuata göre hazırlanan finansal verilerinin piyasa değerlerini açıklama gücü $\% 80,5$ olarak bulurken, UFRS'ye göre hazırlanan finansal verilerinin piyasa değerlerini açıklama gücü \%84,7 olarak hesaplanmıştır. Yazar, bu sonucun UFRS temelli finansal bilgilerin yatırımcılar tarafından daha doğru, kaliteli ve güvenilir algılandığını vurgulamıştır. Gjerde vd. (2008), çalışmalarında Oslo Borsasında faaliyet gösteren 145 Norveçli firmanın UFRS öncesi ve sonrası finansal tabloları üzerinde durmuşlardır. Analizleri sonucunda UFRS 'nin istatistiksel olarak piyasa değeri verileri ile Norveç yerel mevzuatına göre az bir üstünlüğü olduğunu gözlemlemişlerdir. Gjerde vd. (2008), çalışmalarında Oslo Borsasında faaliyet gösteren 145 Norveçli firmanın UFRS öncesi ve sonrası finansal tabloları üzerinde durmuşlardır. Analizleri sonucunda UFRS 'nin istatistiksel olarak piyasa değeri verileri ile Norveç yerel mevzuatına göre az bir üstünlüğü olduğunu gözlemlemişlerdir. Türel (2009), çalışmasında 2001-2002 ve 2005-2006 dönemlerinde Türkiye'de faaliyet göstermiş halka açık firmaları yerel mevzuat ve UFRS açısından karşılaştırmıştır. Analiz sonucunda UFRS 'ye göre raporlama yapmanın istatistiksel olarak firmaların finansal verileri ile piyasa değeri ilişkileri arttırdığı sonucuna ulaşılmıştır. Byard vd. (2010), Avrupa'da faaliyet gösteren firmalardan oluşturduğu örnekleminde iki ayrı grup kullanarak, gönüllü ve zorunlu UFRS adaptasyonunun sonuçlarına odaklanmışlar ve zorunlu olarak UFRS raporlamasına geçen firmaların gönüllülere göre çok daha stabil ve düzgün veri aktarımı sağladığı ve bu nedenle yatırımcılar ve araştırmacılar tarafindan daha güvenilir olarak görüldüğü sonucuna ulaşılmışlardır. Oliveira vd. (2010) ise, çalışmalarında Portekiz Borsası'nda 1998 - 2008 yılları arasında faaliyet gösteren firmaları panel veri analizi kullanarak analiz etmişlerdir. Literatürde yer alan diğer çalışmalardan farklı olarak yazarlar, analizlerinde defter değeri ve dönem net karı değişkenlerine ek olarak maddi olmayan duran varlıklar ve şerefiye kalemlerini de dahil etmişler ve dönem net karı kaleminin istatistiksel olarak anlamlı sonuç vermediğine; maddi olmayan duran varlıklar açısından UFRS ile yerel mevzuat raporlaması arasında bir farklılık olmadığına; bunlara karşın analizlerde diğer 
değişkenlerden UFRS lehine sonuçlar elde edildiği sonuçlarına ulaşmışlardır. Filip ve Raffournier (2010), çalışmalarında Bükreş Borsası'nda faaliyet gösteren Romanya firmalarını ele almışlardır. Yazarlar önceki çalışmalarda yer alan analiz tekniklerini kendi verilerine uyguladıklarında istatistiksel olarak anlamlı sonuçlara ulaşamamışlardır. Bunun nedeni olarak, Bükreş Borsası'nın tam olarak derinliği oluşmamış, olgun olmayan bir borsa niteliği taşıması olarak ifade etmişlerdir. Horton ve Serafeim (2010), İngiltere'de 2005 yılında yürürlüğe alınan UFRS-1 standardının yatırımcıların kanaatlerine etkisini araştırmışlar ve firmaların zorunlu olarak UFRS adaptasyonunun yatırımcıların hisse senedi fiyatlarına olan kanaatlerini etkilediği sonucuna ulaşmışlardır. Iatridis ve Rouvolis (2010), Atina Borsası'nda faaliyet gösteren firmalar üzerine odaklanmış ve UFRS adaptasyonunu birden fazla açıdan ele almışlardır. Yazarların, finansal veri piyasa değeri ilişkisi açısından yapmış oldukları analizler, UFRS ile raporlama yapmanın yerel mevzuata göre daha başarılı bilgi ortaya çıkardığını sonucunu vermiştir. Clarkson vd. (2011), UFRS adaptasyonunu Avusturalya ve Avrupa açısından doğrusal olmayan regresyon teknikleri kullanılarak incelemişler ve UFRS öncesi ve sonrasına ilişkin farklılıklar yakalamış ve finansal veri piyasa değeri ilişkisinde UFRS 'nin yararlarını ortaya koymuşlardır. Tsalavoutas vd. (2012), çalışmalarında 2004 yılında Yunanistan'da faaliyet gösteren firmaların UFRS adaptasyonu öncesi ve sonrası finansal veri piyasada değeri ilişkisinde değişiklik tespitini incelemişler ve dönem net karı açısından istatistiksel anlamlılığın düştüğünü tespit ederken, defter değeri değişkeninin istatistiksel anlamlılığında UFRS sonrası ciddi bir artış gözlemlemişlerdir. Suadiye (2012), finansal veri piyasa değeri ilişkisini Türkiye açısından 2000 - 2002 ve 2005 - 2009 dönemleri karşılaştırması yaparak incelemiştir. Analizler sonucunda UFRS sonrası finansal raporlamada finansal veri piyasa değeri ilişkisinin önemli ölçüde arttı̆̆ı gözlemlenmiştir. Ayrıca, defter değeri değişkeninin UFRS sonrası ilişki derecesinde istatistiksel olarak daha yüksek bir performans tespit edilmiştir. Amerika'da faaliyet gösteren yerel ve yabancı firmaları inceleyen Barth vd. (2012), çalışmalarında UFRS adaptasyonu öncesi ve sonrası performans karşılaştırması yapmışlar ve Amerikan firmalarının UFRS adaptasyonunda daha başarılı olduğu görüşmüş, ayrıca UFRS öncesi ve sonrası finansal veri piyasa değeri ilişkileri açısından da istatistiksel olarak anlamlı artışlar gözlenmişlerdir. Palea (2013), İtalyan firmalarından oluşturduğu bir örneklem ile UFRS öncesi ve sonrası finansal veri piyasa değeri ilişkisini incelemiş ve URFS 'nin yerel mevzuata göre açıklama gücünün çok daha yüksek olduğu bulgusu elde etmiştir. Sultanoğlu (2014), çalışmasında Borsa İstanbul imalat sanayi sektöründe devamlı olarak işlem gören 26 işletme için 2005 y1lı öncesi ve sonrası için analizler gerçekleştirmiştir. Çalışmada, UFRS'nin, finansal bilginin ihtiyaca uygunluğunda bir artış yaratıp yaratmadığını ölçmek için, Fiyat Modeli ve Getiri Modeli, finansal tablo analizi üzerindeki etkisi için ise Rasyo Modeli kullanılarak panel regresyon analizi gerçekleştirilmiş, UFRS'den sonra, finansal bilginin ihtiyaca uygunluğunda anlamlı bir artış olduğu görülmüştür. 
Geçmişte yapılan çalışmalarda karşıt görüşlere odaklanılacak olursa, UFRS aleyhine elde edilen sonuçlar Çin Halk Cumhuriyeti, Almanya, Portekiz, İsveç ve Finlandiya piyasaları için yapılan çalışmalarda elde edilmiştir. Bu çalışmalar genel olarak incelendiğinde aleyhte görüş bildirmelerinin belli başlı sonuçları olduğu görülmektedir. Öncelikle, çalışmalardaki ortak kanı örneklem farklılığı olarak belirtilmektedir. Çalışmalarına lehte sonuç bulma önsezisi ile başladıklarını belirten yazarlar örneklem seçiminden kaynaklanan bir farklılık olduğu üzerinde durmaktadır. Özellikle UFRS geçişinin gerçekleşmesinin hemen ardından yeterli veri elde edilmeden yapılan çalışmalarda bu durum gözlemlenebilmektedir. Bir diğer ortak neden, kullanılan teknik üzerine yoğunlaşmaktadır. Yazarlar kendilerinden önce yapılan çalışmalara göre çeşitli modifikasyonlar ile analizlerini gerçekleştirmekte ve bu nedenle farklı sonuçlara ulaştıklarını ifade etmektedirler. Ortak nedenler dışında incelenen ülkelerin kendi dinamikleri üzerinde durularak da genel literatür içerisinde aleyhte sonuç elde eden çalışmaları incelemek mümkündür. Örneğin, Çin Halk Cumhuriyeti yukarıda da belirtildiği üzere kapalı ekonomi tarzından liberal ekonomiye son yıllarda hızlı geçiş içerisinde olan bir piyasaya sahiptir. Ne kadar liberal dinamiklerin birçoğunu faaliyete geçirmiş olsa da halen tam anlamıla işleyen bir piyasaya sahip olmaması, bu ülke piyasasından elde edilen verilerin bir süre daha sonra analiz edilmesi gerekliliğini göstermektedir. Çin Halk Cumhuriyeti’nde Ohlson ve Getiri Modeli kullanarak araştırmasını yapan Lin ve Chen (2005), 1995-2000 yıllarında faaliyet gösteren yıllık 53 ile 79 firma arasında değişen rakamlarla analizlerin yapıldığı çalışmada, yerel mevzuatın UFRS 'ye göre çok daha başarılı sonuçlar verdiği sonucuna ulaşılmıştır. Frankfurt Borsası'nda faaliyet gösteren Alman firmaları inceleyen Schiebel (2006) 'de Almanya'da yapılan birçok çalışmanın aksine bir sonuç elde etmiştir. 2000 - 2004 yıllarını kapsayan araştırmasında panel veri analizini kullanan yazar, finansal veri piyasa değeri açısından Alman yerel mevzuatının UFRS 'ye göre çok daha anlamlı olduğunu istatistiksel olarak ortaya koymuştur. Morais ve Curto (2008), halka açık faaliyet gösteren Portekiz firma örneklemi üzerine yaptıkları çalışmada da yarı anlamlı bir sonuca ulaşan vatandaşı Oliveira vd. (2010) 'nın aksine kesin ve negatif bir sonuca varmıştır. 34 firmanın kullanıldığı çalışmada firmaların 1995 - 2004 ve 2004 - 2005 yı1larına ait finansal tablo verileri kullanılmıştır. 2005 öncesinin yerel mevzuatı, sonrasının ise UFRS döneminin temsil edildiği analizlerde UFRS adaptasyonunun modelin açıklama gücünü düşürdüğü tespit edilmiştir. Yazarlar elde ettikleri sonuç karşısında öz eleştiride de bulunmuş ve karşılaştırdıkları dönemler açısından gözlem sayılarından kaynaklanan bir durum olabileceğine vurgu yapmışlardır. Paananen (2008) ise, çalışmasında halka açık İsveç firmalarını incelemiş ve UFRS ile finansal raporlamanın finansal verilerin piyasa değerini açıklama gücünde herhangi bir değişikliğe yol açmadığı, dahası finansal bilgilerin kalitesi noktasında düşüş yaşandığı sonucuna ulaşılmıştır.

İncelenen çalışmalar içerisinde araştırma sonuçları açısından son grup UFRS ile raporlamada herhangi istatistiksel olarak anlamlı bir farklılık belirlenemeyen çalışmalardır. Finansal veriler ile piyasa değeri arasındaki ilişkinin incelendiği bu grup çalışmaların 
analizleri sonucunda yerel mevzuat ve UFRS ile raporlama yapılması arasında istatistiksel olarak anlamlı bir farklılık tespit edilememiştir. Bu durumun piyasaların işleyiş biçiminden kaynaklandığı kadar, incelenen ülkelerdeki borsa altyapı sisteminin de yetersiz olmasından kaynaklandığı ifade edilmiştir. Niskanen vd. (2000), Finlandiya’da faaliyet gösteren firmalar üzerine yaptıkları çalışmalarında inceledikleri dönemde, yerel mevzuat ile UFRS ile raporlama arasında istatistiksel anlamlılık olarak ciddi bir farkll1ık gözlemleyememiştir. Eccher ve Healy (2000), çalışmalarında Çin Halk Cumhuriyeti'nde faaliyet gösteren halka açık firmalar üzerinde durmuşlardır. Çin Halk Cumhuriyeti'nin son yıllarda liberal ekonomiye geçiş yaptığının vurgulandığı çalışmada, elde edilen veriler ışında yapılan analizlerde birkaç kısıt üzerinde durulmuştur. Çalışmanın en önemli kısııtı ülkede faaliyet gösteren halka açık firmaların hisse senetlerinin sadece uluslararası yatırımcilar tarafindan talep edilebiliyor olmasıdır. Bu durumun finansal veriler ile piyasa değeri arasındaki ilişkinin kuvvetini ciddi derecede arttığı belirtilmiştir. Analizler sonucunda yerel mevzuat ve UFRS ile raporlama yapılması arasında istatistiksel olarak anlamlı bir farklılık tespit edilememiştir. Bu durumun piyasanın işleyiş biçiminden kaynaklandığı kadar, ülkedeki borsa altyapı sisteminin de yetersiz olmasından kaynaklandığı ifade edilmiştir.

\section{VERİ VE METODOLOJİ}

Araştırmanın amacı Türkiye'de TMS/TFRS uygulamalarının halka açık şirketlerin piyasa değerleri üzerindeki açıklama gücünün Muhasebe Sistemi Uygulama Genel Tebliği (MSUGT) ile karşılaştırarak analiz etmektir. Test edilmek istenen hipotez IASB'nin standartların oluşturulmasındaki temel hedefi olan kaliteli, anlaşılır, genel kabul görmüş ve küresel muhasebe bilgisinin Türkiye piyasasında oluşup oluşmadığının araştırılmasıdır. TMS/TFRS ile oluşturulan finansal tabloların yatırımeı tarafindan daha kaliteli ve doğru kabul edilmesinin şirketlerin piyasa değerlerine yansımış olması beklentisi çalışmanın temel varsayımıdır. Analizler sonucunda, TMS/TFRS uygulamalarının BİST'de faaliyet gösteren halka açık şirketlerin piyasa değerlerini açıklama gücü, MSUGT uygulamalarına göre daha yüksek çıkacak olursa, IASB amaçlarının lehine bir sonuca ulaşılmış olacaktır.

Çalışmada araştırmanın amacı doğrultusunda değişkenler iki ayrı dönem için oluşturulmaktadır. Bu dönemler, MSUGT uygulamalarını temsil edecek olan 2000-2004 dönemlerini ve TMS/TFRS uygulamalarını temsil edecek olan 2005-2009 dönemlerini kapsamaktadır. Veri setine, 2000-2009 döneminde BİST'de faaliyet gösteren, MSUGT uygulamalarını kullanıyor olup 2005 yılında TMS/TFRS uygulamalarını kullanmaya başlayan 225 adet halka açık şirket dahil edilmiştir. Bu özelliği ile çalışma konu ile ilişkili olan ve belirlenen dönemde Türkiye'de faaliyet gösteren tüm şirketleri kapsamaktadır. Türkiye'de 2005 sonrası tüm halka açık şirketlerin TMS/TFRS uygulamalarına geçmiş olması, çalışma dönemlerinin belirlenmesindeki temel noktayı meydana getirmektedir. Temsil yıllarının beşer yıllık dönemler şeklinde sınırlandırılmasındaki kısıt ise, uygulama değişimi ile karşı karşıya kalmış şirket sayısının 2000-2009 yılları arasında maksimum sayıya ulaşmasıdır. Daha net bir 
ifade ile açıklanacak olursa, araştırmanın başlangıç yılının daha geçmişe; bitiş yılının da daha ileriye genişletilmesi analizde kullanılabilecek olan gözlem sayısını azaltmaktadır. Bu nedenle maksimum gözleme ulaşılabilen beş yıllık pencereler seçilmiştir. Analizlerde kullanılan model değişkenleri $i$ şirketinin $t$ tarihinde borsadaki piyasa değerini ifade eden piyasa değeri değişkeni $\left(P_{\text {it }}\right)$; $i$ şirketinin $t$ tarihindeki gelir tablosundaki dönem karını ifade eden dönem karı değişkeni $\left(E_{i t}\right)$; son olarak da $i$ şirketinin $t$ tarihindeki bilançosundaki özkaynakları ifade eden defter değeri değişkeni $\left(B V_{i t}\right)$ şeklinde belirlenmektedir. İlgili değişkenler şirketlerin Borsa İstanbul internet sayfasında ve Kamu Aydınlatma Platformu ${ }^{1}$ internet sayfasında yayınlanan yıllık finansal tablolarından elde edilmektedir. Piyasa değeri değişkeni $\left(P_{\text {it }}\right)$, hisse senetleri piyasası değerleme oranları veri seti içerisinden elde edilirken; dönem karı değişkeni $\left(E_{i t}\right)$, her bir şirketin yıllık gelir tablosundan, defter değeri değişkeni $\left(B V_{i t}\right)$ de yıllık bilançolardan elde edilmektedir.

Araştırmanın analiz sürecinde literatürde benzer araştırmayı yapan araştırmacıların kullandığı modeller üzerinden hareket edilecektir. Bu anlamda Ohlson Modeli (Ohlson, 1995) temel olmak üzere geliştirilen, Standartlaştırılmış Ohlson Modeli (Harris ve Muller, 1999) ve Üstel (Explonential) Ohloson Modeli (Schiebel, 2006) isimli değerleme modelleri üzerinde durulacaktır. İlgili modeller sırasıyla Eşitlik 1, Eşitlik 2 ve Eşitlik 3 'te gösterilmektedir.

$$
\begin{aligned}
& P_{i t}=\beta_{0}+\beta_{1} E_{i t}+\beta_{2} B V_{i t}+\varepsilon_{i t} \\
& P_{i t} / P_{i, t-1}=\beta_{0}+\beta_{1}\left(E_{i t} / P_{i, t-1}\right)+\beta_{2}\left(B V_{i t} / P_{i, t-1}\right)+\varepsilon_{i t} \\
& P_{i t}=\beta_{0} * E_{i t}^{\beta_{1}} * B V_{i t}^{\beta_{2}} * \varepsilon_{i t}
\end{aligned}
$$

Eşitliklerde;

$P_{\text {it }} \quad:$ i şirketinin t tarihinde borsadaki piyasa değeri,

$P_{i, t-1}:$ i şirketinin (t-1) tarihinde borsadaki piyasa değeri,

$E_{\text {it }} \quad:$ i şirketinin $\mathrm{t}$ tarihindeki gelir tablosundaki dönem karı,

$B V_{i t} \quad$ : i şirketinin $\mathrm{t}$ tarihindeki bilançosundaki özkaynakları (defter değeri),

$\beta_{0,1,2}$ : Model katsay1lar1,

$\varepsilon_{i t} \quad$ : Hata terimini ifade etmektedir.

Analizlerin ilk aşamasında veriler ve dönem aralığından kaynaklanan kısıtlar nedeniyle Eşitlik 3'te yer alan Üstel (Explonential) Ohloson Modeli çalışma dışı birakılmak zorunda kalmıştır. Üstel modelin regresyon analizine tabi tutulabilmesi için öncelikle doğrusallaştırılması gerekmektedir. Bunun için logaritmik dönüşüm uygulanır. Ancak veri setinde negatif değerin bulunması logaritmik dönüşümü olanaksız kılmaktadır. Bu nedenle Üstel (Explonential) Ohloson Modeli çalışma dışı bırakılmıştır.

Analizlerde kullanılacak olan bir diğer model seti ise, Ohlson ve Standartlaştırılmış Ohlson modellerinde yer alan dönem karı ve defter değeri değişkenlerinin tek tek (step-by-

\footnotetext{
${ }^{1}$ Borsa İstanbul: www.borsaistanbul.com, Kamu Aydınlatma Platformu: www.kap.gov.tr
} 
step) piyasa değeri üzerindeki ilişkisini incelemeye yönelik olarak belirlenmiştir. Bağımsız değişkenlerin tek tek dahil edildiği modeller sırasıyla Eşitlik 4, Eşitlik 5, Eşitlik 6 ve Eşitlik 7'de gösterilmektedir.

$$
\begin{aligned}
& P_{i t}=\beta_{0}+\beta_{1} E_{i t}+\varepsilon_{i t} \\
& P_{i t}=\beta_{0}+\beta_{1} B V_{i t}+\varepsilon_{i t} \\
& P_{i t} / P_{i, t-1}=\beta_{0}+\beta_{1}\left(E_{i t} / P_{i, t-1}\right)+\varepsilon_{i t} \\
& P_{i t} / P_{i, t-1}=\beta_{0}+\beta_{1}\left(B V_{i t} / P_{i, t-1}\right)+\varepsilon_{i t}
\end{aligned}
$$

Açıklanan modeller kullanılarak uygulanacak olan panel veri analizinde bir takım yöntemler kullanılmaktadır. Modellerin tahminine geçmeden önce, parametrelerin birim ve/veya zamana göre değer almasına bağlı olarak bazı testler yapılması gerekmektedir. $\mathrm{Bu}$ amaçla tüm modeller için F-testi uygulanması gerekmektedir. Sonraki aşamada tahminci seçiminin yapılabilmesi için Hausman testi uygulanmaktadır. Hausman testi sonrasında hata teriminin değişen varyansa ve/veya otokorelasyona sahip olabileceği ihtimali nedeniyle değiş̧en varyansı test etmek için en çok kullanılan testlerden biri olan Modified Wald Değişen Varyans testi ve otokorelasyonu test etmek amaciyla da Wooldridge Otokorelasyon testi uygulanmaktadır. Ampirik çalışmaların birçoğunda kalıntılar arasında eşdönemli korelasyon olması beklenebilir ve bu korelasyonların istatistiksel olarak anlamlılığını sınanmak için Pesaran'ın Yatak Kesit Bağımlılığı testi uygulanmaktadır. Bahsi geçen tüm testlerin yapılmasının ardından son olarak panel birim kök sınamasının yapılması gerekmektedir. Ancak birinci ve ikinci nesil panel birim kök testleri eldeki verinin doğrusal bir süreç tarafından üretildiğini ve veri üretme sürecinde yapısal bir kırılma meydana gelmediğini varsaymaktadır. Birim kök testi uygulamasında yapısal kırılmanın dikkate alınmaması sapmalı sonuçlara neden olabilmektedir (Güloğlu ve İspir, 2009). Bu nedenle Carrion-iSilvestre ve diğerlerinin (2005) geliştirdikleri panel birim kök sınamasında çoklu kırılma durumunu dikkate alan PANKPSS testi kullanılmaktadır. Tüm analizlerin tamamlanmasının ardından çalışma amacı doğrultusunda kullanılacak olan dirençli tahmin sonuçları, Beck-Katz (1995) Panel Düzeltilmiş Standart Hataları tahmincisi ile tahmin edilmektedir. ${ }^{2}$

\section{ARAȘTIRMA SONUÇLARI}

Model tahminlerine ve bulguların yorumuna geçmeden önce bağımsız değişkenler arasındaki korelasyonun incelenmesi gerekmektedir. $\mathrm{Bu}$ amaçla Ohlson ve Standartlaştırılmış Ohlson modellerinde yer alan bağımsız değişkenlerin korelasyon matrisleri Tablo 1'de gösterilmektedir.

\footnotetext{
${ }^{2}$ Detaylı bilgi için bkz: Uyar (2015).
} 
Tablo 1. Değişkenler Arası Korelasyon Matrisleri

\begin{tabular}{|c|c|c|c|c|c|c|}
\hline & & $\boldsymbol{B} \boldsymbol{V}_{\text {it }}$ & $E_{i t}$ & & $B V_{i t} / P_{i, t-1}$ & $E_{i t} / P_{i, t-1}$ \\
\hline \multirow{2}{*}{ 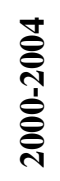 } & $B V_{i t}$ & 1.000 & 0.8518 & $B V_{i t} / P_{i, t-1}$ & 1.000 & 0.3254 \\
\hline & $E_{i t}$ & 0.8518 & 1.000 & $E_{i t} / P_{i, t-1}$ & 0.3254 & 1.000 \\
\hline \multirow{2}{*}{ 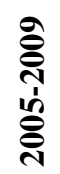 } & $B V_{i t}$ & 1.000 & 0.8728 & $B V_{i t} / P_{i, t-1}$ & 1.000 & 0.3871 \\
\hline & $E_{i t}$ & 0.8728 & 1.000 & $E_{i t} / P_{i, t-1}$ & 0.3871 & 1.000 \\
\hline
\end{tabular}

Tablo 1'de yer alan korelasyon matrisleri incelendiği takdirde Ohlson modeline birlikte dahil edilmesi planlanan dönem karı $\left(E_{i t}\right)$ ve defter değeri $\left(B V_{i t}\right)$ değişkenlerinin yüksek oranda korelasyonlu olduğu görülmektedir. Bu durum model tahminin çoklu doğrusal bağımlılığa neden olacağı için Eşitlik 1'in çalışma dışı bırakılmasına karar verilmiştir.

TMS/TFRS uygulamalarının MSUGT uygulamaları ile karşılaştııılması amacıyla uygulanan panel veri analizinde model tahminine geçmeden uygulanacak analizler belirlenen iki dönem için ayrı ayrı gerçekleştirilecektir. Bu analiz sonuçları ve bulguların yorumları 2000-2004 ve 2005-2009 dönemleri için ayrı ayrı incelenecektir. Analizler başta belirtildiği üzere Eşitlik 2, 4, 5, 6 ve 7 'de yer alan Ohlson Modelleri ve Standartlaştırılmış Ohlson Modelleri için yapılacaktır. Üstel (Explonential) Ohloson Modeli logaritmik dönüşümün ilgili dönemlerde değişkenlerde negatif değerlerin yer alması nedeniyle; Eşitlik 1'de yer alan Ohlson Modeli ise çoklu doğrusal bağlılık sorunu nedeniyle çalışma dışı bırakılmak zorunda kalkmıştır. Çalışmada Ohlson Modelleri ve Standartlaştırılmış Ohlson Modelleri için panel veri analizi kullanılarak analizler gerçekleştirilecektir. Modellerin tahminine geçmeden önce yapılması gereken analizler sırasıyla açıklandıktan sonra dirençli tahmin sonuçları TMS/TFRS ve MSUGT uygulamalarını temsil eden dönemler için açıklama güçleri açısından karşılaştırılacaktır.

Panel veri analizi uygulamasında ilk olarak, parametrelerin birim ve/veya zamana göre değer almasına bağlı olarak yapılması gereken testlerden F-testi uygulanması yapılmıştır. 2000-2004 ve 2005-2009 dönemleri için ayrı ayrı incelenen F-testi sonuçlarına göre modellerde birim ve zaman etkilerine rastlanmıştır. Bir sonraki aşamada modellere Hausman testi uygulanmıştır. Hausman testi ise sabit etkiler ve rassal etkiler modeli arasında yapılacak bir seçim için kullanılan bir model değil, aslında bir tahminci seçimidir. Hata terimleri ile açıklayıcı değişkenler arasındaki ilişkinin olmadığı varsayımının sağlanmaması durumunda rassal etkiler tahmincisi tutarsız olacaktır. Bu durumda tutarlı olan sabit etkiler tahmincisi tercih edilmektedir. Çalışmada kullanılan modellere ilişkin Hausman test istatistiklerine Tablo 2'de yer verilmiştir. 
Tablo 2. Hausman Test İstatistikleri

\begin{tabular}{|c|c|c|c|}
\hline 2000-2004 & \multirow{2}{*}{ Eşitlik } & \multicolumn{2}{|c|}{$\begin{array}{c}\text { Hausman Test } \\
\text { İstatistikleri }\end{array}$} \\
\hline Modeller & & $\begin{array}{c}\chi^{2} \\
\text { Değeri }\end{array}$ & $\begin{array}{l}\text { Olasılık } \\
\text { Değeri }\end{array}$ \\
\hline$P_{i t}=\beta_{0}+\beta_{1} E_{i t}+\varepsilon_{i t}$ & (4) & 225.55 & $0.000^{*}$ \\
\hline$P_{i t}=\beta_{0}+\beta_{1} B V_{i t}+\varepsilon_{i t}$ & (5) & 142.84 & $0.000^{*}$ \\
\hline$P_{i t} / P_{i, t-1}=\beta_{0}+\beta_{1}\left(E_{i t} / P_{i, t-1}\right)+\beta_{2}\left(B V_{i t} / P_{i, t-1}\right)+\varepsilon_{i t}$ & (2) & 41.88 & $0.000^{*}$ \\
\hline$P_{i t} / P_{i, t-1}=\beta_{0}+\beta_{1}\left(E_{i t} / P_{i, t-1}\right)+\varepsilon_{i t}$ & (6) & 2.69 & 0.6107 \\
\hline$P_{i t} / P_{i, t-1}=\beta_{0}+\beta_{1}\left(B V_{i t} / P_{i, t-1}\right)+\varepsilon_{i t}$ & (7) & 46.58 & $0.000^{*}$ \\
\hline 2005-2009 & \multirow{2}{*}{ Eşitlik } & \multicolumn{2}{|c|}{$\begin{array}{c}\text { Hausman Test } \\
\text { İstatistikleri }\end{array}$} \\
\hline Modeller & & $\begin{array}{c}\chi^{2} \\
\text { Değeri }\end{array}$ & $\begin{array}{l}\text { Olasılık } \\
\text { Değeri }\end{array}$ \\
\hline$P_{i t}=\beta_{0}+\beta_{1} E_{i t}+\varepsilon_{i t}$ & (4) & 364.90 & $0.000^{*}$ \\
\hline$P_{i t}=\beta_{0}+\beta_{1} B V_{i t}+\varepsilon_{i t}$ & (5) & 138.83 & $0.000^{*}$ \\
\hline$P_{i t} / P_{i, t-1}=\beta_{0}+\beta_{1}\left(E_{i t} / P_{i, t-1}\right)+\beta_{2}\left(B V_{i t} / P_{i, t-1}\right)+\varepsilon_{i t}$ & (2) & 22.94 & $0.001^{*}$ \\
\hline$P_{i t} / P_{i, t-1}=\beta_{0}+\beta_{1}\left(E_{i t} / P_{i, t-1}\right)+\varepsilon_{i t}$ & (6) & 1.27 & 0.9375 \\
\hline$P_{i t} / P_{i, t-1}=\beta_{0}+\beta_{1}\left(B V_{i t} / P_{i, t-1}\right)+\varepsilon_{i t}$ & (7) & 25.24 & $0.000^{*}$ \\
\hline
\end{tabular}

$* 0.01, * * 0.05, * * * 0.10$, anlamlllık düzeylerini ifade etmektedir.

Tablo 2'ye göre, 2000-2004 dönemlerine ait analizlerde, ilk üç modelde ve Eşitlik 7'de sıfır hipotezi reddedilmektedir. Bu modeller için tutarlı olan sabit etkiler tahmincisi kullanılabilir. Eşitlik 6 için ise sabit etkiler tahmincisi tutarlıyken, rassal etkiler tahmincisi etkindir ve iki tahminciden birisi kullanılabilir. 2005-2009 dönemlerine ait analizlerde ilk üç model ve Eşitlik 7 için \%5 anlamlılık düzeyinde sıfır hipotezi reddedilebilirken, Eşitlik 6 için ise sıfir hipotezi reddedilememektedir. Sonuçlar ilk dönemde olduğu gibi değerlendirilmektedir.

Analizlerin bir sonraki aşamasında değişen varyans ve otokorelasyon testleri uygulanmıştır. Hata terimlerinin, değişen varyansa ve/veya otokorelasyona sahip olabileceği durumunların tespit edilmesi için yapılan testlerde; değişen varyansı test etmek için Modified Wald Değişen Varyans Testi, otokorelasyonu test etmek için Wooldridge Otokorelasyon Testi kullanılmıştır. Yapılan testler sonucunda 2000-2004 ve 2005-2009 dönemleri için tüm modellerde \%1 anlamlılık düzeyinde değişen varyans olduğuna karar verilmektedir. 2000- 
2004 dönemi için belirlenen modellere ilişkin otokorelasyon test istatistiklerine göre de Eşitlik 6 hariç diğer modellerde $\% 1, \% 5$ ve $\% 10$ anlamll1ık düzeylerinde birinci mertebeden otokorelasyon olduğuna karar verilmiştir. 2005-2009 dönemi için ise Eşitlik 6 ve 7 dışında diğer tüm modellerde $\% 5$ ve $\% 10$ anlamll1ık düzeylerinde birinci mertebeden otokorelasyon olduğuna karar verilmiştir.

Değişen varyans ve otokorelasyon testlerinin uygulamasından sonra modellerde yatay kesit bağlılığının incelenmesi aşamasına geçilmiş̧ir. Yatay kesit bağımlılı̆̆ ile ilgili ampirik çalışmaların birçoğunda kalıntılar arasında eşdönemli korelasyon olması beklenebilir ve bu korelasyonların istatistiksel olarak anlamlılığını sınanmak için en yaygın şekilde kullanılan testlerden biri de Breusch ve Pagan (1980) LM sinamasıdır. Ancak Pesaran (2004) N'nin ve T'nin büyük olduğu durumlar için $C D_{L M 2}$ olarak adlandırdığı istatistiği türetmiştir. $\mathrm{N}>\mathrm{T}$ durumu için kalıntılar arasındaki korelasyonun sıfır olduğu hipotezinin CD istatistiğiyle sınanması gerektiği ifade edilmektedir. Bu nedenle, tüm modeller için Pesaran Yatay Kesit Bağımlılığı testi uygulanmıştır. 2000-2005 ve 2005-2009 dönemleri Pesaran yatay kesit bağımlılığ 1 test istatistikleri incelendiğinde ise, tüm modellerde yatay kesit bağımlılığının olduğu sonucuna ulaşılmıştır. Buna göre tüm modeller için de yatay kesit bağımlılığını dikkate alan ikinci nesil birim kök testi uygulanması gerektiğine karar verilmiştir. Ancak, birinci ve ikinci nesil panel birim kök testleri eldeki verinin doğrusal bir süreç tarafindan üretildiğini ve veri üretme sürecinde yapısal bir kırılma meydana gelmediğini varsaymaktadır. Birim kök testi uygulamasında yapısal kırılmanın dikkate alınmaması sapmalı sonuçlara neden olabilmektedir. Bu nedenle Carrion-i-Silvestre vd. (2005) geliştirdikleri panel birim kök sınamasında çoklu kırılma durumunu dikkate alan Panel KPSS (PANKPSS) testinin kullanılması uygun görülmüştür. PANKPSS Birim Kök testi sonuçları Tablo 3 ve 4 'te gösterilmektedir. 
Tablo 3. 2000-2004 Dönemi Panel KPSS ${ }^{3}$ Birim Kök Test ${ }^{4}$ İstatistikleri

(Sabitli ve Trendli)

\begin{tabular}{|c|c|c|c|c|c|c|}
\hline \multicolumn{7}{|c|}{ Yapısal Kırılma Tarihleri ve Panel KPSS Sınama Sonuclan (Sabitli ve Trendli) } \\
\hline 2000-2004 & \multirow{2}{*}{ Kurılma Sayıs } & \multirow{2}{*}{ Tb,1 } & \multirow{2}{*}{ Tb,2 } & \multirow{2}{*}{ Tb,3 } & \multirow{2}{*}{ Tb,4 } & \multirow[b]{2}{*}{ Tb,5 } \\
\hline Değişkenler & & & & & & \\
\hline$P_{\text {it }}$ & 3 & 2001 & 2003 & 2004 & & \\
\hline$\overline{E_{i t}}$ & 2 & 2001 & 2004 & & & \\
\hline$B V_{i t}$ & 2 & 2001 & 2004 & & & \\
\hline \multicolumn{7}{|c|}{ Panel Birim Kök Sınaması } \\
\hline \multirow{3}{*}{$P_{i t}$} & Model & \multicolumn{2}{|c|}{ Test İstatistiği } & \multicolumn{3}{|c|}{ Asimtotik Kritik Değer } \\
\hline & LM $(\lambda)($ hom) & \multicolumn{2}{|l|}{0.759} & \multicolumn{3}{|c|}{0.224} \\
\hline & LM $(\lambda)($ het $)$ & \multicolumn{2}{|l|}{0.759} & \multicolumn{3}{|c|}{0.224} \\
\hline \multirow{3}{*}{$E_{i t}$} & Model & \multicolumn{2}{|c|}{ Test İstatistiği } & \multicolumn{3}{|c|}{ Asimtotik Kritik Değer } \\
\hline & LM $(\lambda)($ hom) & \multicolumn{2}{|l|}{0.035} & \multicolumn{3}{|c|}{0.486} \\
\hline & LM $(\lambda)($ het) & \multicolumn{2}{|l|}{0.035} & \multicolumn{3}{|c|}{0.486} \\
\hline \multirow{3}{*}{$B V_{i t}$} & Model & \multicolumn{2}{|c|}{ Test İstatistiği } & \multicolumn{3}{|c|}{ Asimtotik Kritik Değer } \\
\hline & LM (ג)(hom) & \multicolumn{2}{|l|}{0.039} & \multicolumn{3}{|c|}{0.484} \\
\hline & LM $(\lambda)($ het) & \multicolumn{2}{|l|}{0.039} & \multicolumn{3}{|c|}{0.484} \\
\hline
\end{tabular}

$* 0.01, * * 0.05, * * * 0.10$, anlamlılık düzeylerini ifade etmektedir.

Tablo 3’te 2000-2004 dönemine ait sabitli ve trendli panel KPSS birim kök testi istatistikleri bulunmaktadır. Sonuçlar incelendiğinde piyasa değeri $\left(P_{i t}\right)$ serisinde 2001, 2003 ve 2004 yıllarında kırılma meydana gelmiştir; ancak yapısal kırılmaların dikkate alınarak yapıldığı birim kök sinaması sonucuna göre $\left(P_{i t}\right)$ serisinin durağan olduğu sonucuna ulaşılmıştır. Başka bir deyişle yapısal kırılmalar serinin durağanlığını etkilememiştir. Dönem karı $\left(E_{i t}\right)$ değişkeni incelendiğinde ise, 2001 ve 2004 y1llarında kırılmalar olduğu tespit edilmiştir; ancak $\left(E_{i t}\right)$ serisindeki bu kırılmalar da serinin durağanlığını etkilememiştir. Son olarak defter değeri $\left(B V_{i t}\right)$ değişkeni incelendiğinde, 2001 ve 2004 yıllarında kırılmaların meydana geldiği tespit edilmiştir. Yapısal kırılmaları dikkate alan birim kök sınaması sonucuna göre de $\left(B V_{i t}\right)$ serisi de durağandır.

\footnotetext{
${ }^{3}$ KPSS Testi: Kwiatkowski, Phillips, Schmidt ve Shin Testi (Kwiatkowski vd., 1992). Carrion-i-Silvestre vd. (2005) KPSS testini panel veri setine uygulayarak Panel KPSS Birim Kök Testini geliştirmişlerdir.

${ }^{4}$ Sonuçlar yatay kesit bağımlılığını dikkate almaktadır.
} 
Tablo 4. 2005-2009 Dönemi Panel KPSS Birim Kök Test İstatistikleri ${ }^{5}$

(Sabitli ve Trendli)

\begin{tabular}{|c|c|c|c|c|c|c|}
\hline \multicolumn{7}{|c|}{ Yapısal Kırılma Tarihleri ve Panel KPSS Sınama Sonuçlan (Sabitli ve Trendli) } \\
\hline 2005-2009 & \multirow{2}{*}{ Kırılma Sayıs } & \multirow{2}{*}{ Tb,1 } & \multirow{2}{*}{ Tb,2 } & \multirow{2}{*}{ Tb,3 } & \multirow{2}{*}{ Tb,4 } & \multirow{2}{*}{ Tb,5 } \\
\hline Değişkenler & & & & & & \\
\hline$P_{i t}$ & 3 & 2006 & 2007 & 2009 & & \\
\hline$E_{i t}$ & 3 & 2005 & 2007 & 2009 & & \\
\hline$B V_{i t}$ & 2 & 2006 & 2009 & & & \\
\hline \multicolumn{7}{|c|}{ Panel Birim Kök Sınaması } \\
\hline \multirow{3}{*}{$P_{i t}$} & Model & \multicolumn{2}{|c|}{ Test İstatistiği } & \multicolumn{3}{|c|}{ Asimtotik Kritik De ğer } \\
\hline & LM $(\lambda)($ hom) & \multicolumn{2}{|c|}{-0.631} & \multicolumn{3}{|c|}{0.736} \\
\hline & LM $(\lambda)($ het) & \multicolumn{2}{|l|}{-0.631} & \multicolumn{3}{|c|}{0.736} \\
\hline \multirow{3}{*}{$E_{i t}$} & Model & \multicolumn{2}{|c|}{ Test İstatistiği } & \multicolumn{3}{|c|}{ Asimtotik Kritik Değer } \\
\hline & LM $(\lambda)($ hom) & \multicolumn{2}{|l|}{-0.456} & \multicolumn{3}{|c|}{0.676} \\
\hline & LM $(\lambda)($ het $)$ & \multicolumn{2}{|l|}{-0.456} & \multicolumn{3}{|c|}{0.676} \\
\hline \multirow{3}{*}{$B V_{i t}$} & Model & \multicolumn{2}{|c|}{ Test İstatistiği } & \multicolumn{3}{|c|}{ Asimtotik Kritik Değer } \\
\hline & LM ( $(\lambda)($ hom) & \multicolumn{2}{|l|}{0.025} & \multicolumn{3}{|c|}{0.490} \\
\hline & LM $(\lambda)$ (het) & \multicolumn{2}{|l|}{0.025} & \multicolumn{3}{|c|}{0.490} \\
\hline
\end{tabular}

$* 0.01, * * 0.05, * * * 0.10$, anlamlılık düzeylerini ifade etmektedir.

Tablo 4'te 2005-2009 dönemine ait sabitli ve trendli panel KPSS birim kök testi istatistikleri bulunmaktadır. Sonuçlar incelendiğinde piyasa değeri $\left(P_{i t}\right)$ serisinde 2006, 2007 ve 2009 yıllarında kırılma meydana gelmiştir; ancak yapısal kırılmaların dikkate alınarak yapıldığ birim kök sınaması sonucuna göre $\left(P_{\text {it }}\right)$ serisinin durağan olduğu sonucuna ulaşılmıştır. Dönem karı $\left(E_{i t}\right)$ değişkeni incelendiğinde ise, 2005, 2007 ve 2009 yıllarında kırılmalar olduğu tespit edilmiştir; ancak $\left(E_{i t}\right)$ serisindeki bu kırılmalar da serinin durağanlığını etkilememiştir. Son olarak defter değeri $\left(B V_{i t}\right)$ değişkeni incelendiğinde, 2006 ve 2009 yıllarında kırılmaların meydana geldiği tespit edilmiştir. Yapısal kırılmaları dikkate alan birim kök sınaması sonucuna göre de $\left(B V_{i t}\right)$ serisi de durağandır.

Tüm testlerin yapılmasının ardından varsayım ihlalleri de göz önüne alınarak çalışma amacı doğrultusunda kullanılacak olan dirençli tahminci, Beck-Katz (1995) Panel Düzeltilmiş Standart Hataları tahmincisi olarak belirlenmiştir. Beck-Katz, önerdikleri bu yaklaşım ile birimler arası korelasyonu düzeltmek için kullanılabileceğini ve $\mathrm{T}>\mathrm{N}$ durumunda da kullanılabileceğini göstermektedir.

$\mathrm{Bu}$ aşamadan sonra yapılmış olan analizler doğrultusunda modellere zaman etkilerinin dahil edilmesi gerekmektedir. Bu işlem her bir modele anlamlı zaman kuklalarının eklenmesi şeklinde yapılmaktadır. Zaman etkileri tahmin döneminde meydana gelmiş olabilecek yapısal

\footnotetext{
${ }^{5}$ Sonuçlar yatay kesit bağımlılı̆̆ını dikkate almaktadır.
} 
kırılmaların model üzerindeki etkisini belirtmek üzere eklenmektedir ve incelenen dönemlerin büyük krizler içermesi nedeniyle önem arz etmektedir. PANKPSS test sonuçları ile paralellik gösteren ve modellere eklenen zaman kuklaları aşağıdaki eşitliklerde gösterilmektedir.

$$
\begin{aligned}
& P_{i t}=\beta_{0}+\beta_{1} E_{i t}+\beta_{2} D_{i, 2001}+\beta_{3} D_{i, 2003}+\beta_{4} D_{i, 2004}+\varepsilon_{i t} \\
& P_{i t}=\beta_{0}+\beta_{1} E_{i t}+\beta_{2} D_{i, 2007}+\varepsilon_{i t} \\
& P_{i t}=\beta_{0}+\beta_{1} B V_{i t}+\beta_{2} D_{i, 2001}+\varepsilon_{i t}
\end{aligned}
$$

$$
\begin{aligned}
& P_{i t}=\beta_{0}+\beta_{1} B V_{i t}+\beta_{2} D_{i, 2007}+\beta_{3} D_{i, 2008}+\varepsilon_{i t} \\
& P_{i t} / P_{i, t-1}=\beta_{0}+\beta_{1}\left(E_{i t} / P_{i, t-1}\right)+\beta_{2}\left(B V_{i t} / P_{i, t-1}\right)+\beta_{2} D_{i, 2001}+\beta_{3} D_{i, 2003}+\beta_{4} D_{i, 2004}+\varepsilon_{i t} \\
& P_{i t} / P_{i, t-1}=\beta_{0}+\beta_{1}\left(E_{i t} / P_{i, t-1}\right)+\beta_{2}\left(B V_{i t} / P_{i, t-1}\right)+\beta_{2} D_{i, 2005}+\beta_{3} D_{i, 2009}+\varepsilon_{i t} \\
& P_{i t} / P_{i, t-1}=\beta_{0}+\beta_{1}\left(E_{i t} / P_{i, t-1}\right)+\beta_{2} D_{i, 2001}+\beta_{3} D_{i, 2003}+\beta_{4} D_{i, 2004}+\varepsilon_{i t} \\
& P_{i t} / P_{i, t-1}=\beta_{0}+\beta_{1}\left(E_{i t} / P_{i, t-1}\right)+\beta_{2} D_{i, 2006}+\beta_{3} D_{i, 2007}+\beta_{4} D_{i, 2008}+\beta_{5} D_{i, 2009}+\varepsilon_{i t} \\
& P_{i t} / P_{i, t-1}=\beta_{0}+\beta_{1}\left(B V_{i t} / P_{i, t-1}\right)+\beta_{2} D_{i, 2001}+\beta_{3} D_{i, 2003}+\beta_{4} D_{i, 2004}+\varepsilon_{i t} \\
& P_{i t} / P_{i, t-1}=\beta_{0}+\beta_{1}\left(B V_{i t} / P_{i, t-1}\right)+\beta_{2} D_{i, 2006}+\beta_{3} D_{i, 2007}+\beta_{4} D_{i, 2008}+\varepsilon_{i t}
\end{aligned}
$$

Modellerde yer alan $D_{\text {it }}$ kukla değişkenlerindeki $t$ alt indisi zaman etkisini gösteren y1lları ifade etmektedir. Modellerin zaman etkileri ile birlikte belirlenmelerinin ardından model tahmin aşamasına geçmek mümkündür. Türkiye'de TMS/TFRS uygulamalarının halka açık şirketlerin piyasa değerleri üzerindeki açıklama gücünün MSUGT ile karşılaştırarak analiz etmek amacı doğrultusunda gerçekleştirilen panel veri analizini tahmin sonuçlarını, her modelin $\mathrm{R}^{2}$ değeri açısından karşılaştırmak mümkündür. Dirençli tahmin sonuçlarında bağımsız değişkenlerin bağımlı değişkeni açıklama gücünü ifade eden $\mathrm{R}^{2}$ değerleri, Tablo 5 'te özet olarak gösterilmektedir. 
Tablo 5. Dirençli Tahmin Sonuçları $\mathrm{R}^{2}$ Özet Tablosu ${ }^{6}$

\begin{tabular}{|l|c|c|c|c|}
\hline \multirow{2}{*}{ Modeller } & \multicolumn{2}{|c|}{ R $^{2}$ Dönemler } & \multicolumn{2}{c|}{ I. Dönem } \\
\cline { 2 - 5 } & $\mathbf{2 0 0 0 - 2 0 0 4}$ & $2005-2009$ & \multicolumn{2}{|c|}{ II. Dönem } \\
\hline$P_{i t}=\beta_{0}+\beta_{1} E_{i t}+\varepsilon_{i t}$ & & & \multicolumn{2}{|c|}{ Fark } \\
\hline$P_{i t}=\beta_{0}+\beta_{1} B V_{i t}+\varepsilon_{i t}$ & 0.2492 & 0.3450 & ARTIŞ & $38.44 \%$ \\
\hline$P_{i t} / P_{i, t-1}=\beta_{0}+\beta_{1}\left(E_{i t} / P_{i, t-1}\right)+\beta_{2}\left(B V_{i t} / P_{i, t}\right)+1$ & 0.1609 & 0.4703 & ARTIŞ & $192.29 \%$ \\
\hline$P_{i t} / P_{i, t-1}=\beta_{0}+\beta_{1}\left(E_{i t} / P_{i, t-1}\right)+\varepsilon_{i t}$ & 0.5427 & 0.5120 & AZALIŞ & $-5.66 \%$ \\
\hline$P_{i t} / P_{i, t-1}=\beta_{0}+\beta_{1}\left(B V_{i t} / P_{i, t-1}\right)+\varepsilon_{i t}$ & 0.1266 & 0.2630 & ARTIŞ & $107.74 \%$ \\
\hline
\end{tabular}

\section{BULGULARIN YORUMU}

Borsa İstanbul'da faaliyet gösteren halka açık şirketler 2005 y1lında yerel mevzuatı oluşturan MSUGT uygulamalarını terk ederek IASB'nin oluşturduğu ve Türkçe 'ye çevrilen TMS/TFRS uygulamalarını muhasebe sistemi ve finansal tablolar standartları olarak kabul etmiştir. IASB, standartları oluşturmada temel amaç olarak kaliteli, anlaşılır, genel kabul görmüş ve küresel muhasebe bilgisinin oluşturulmasını sağlamayı hedeflemektedir. Bu hedefin Türkiye açısından değerlendirildiği çalışmanın analiz sonucu Tablo 5'te özet olarak sunulmaktadır. Tablo 5 incelendiğinde Ohlson modelleri açısından defter değeri değişkeni ile piyasa değerinin ilişkilendirildiği model haricindeki model $\mathrm{R}^{2}$ değerlerinde artış gözlenmektedir. Standartlaştırılmış Ohlson modelleri açısından ise tüm modellerin $\mathrm{R}^{2}$ değerlerinde artış gözlenmektedir. Yapılan analizlerde sadece defter değeri ve piyasa değeri değişkenlerinin kullanıldığı modelde azalış bulunmaktadır. Fakat azalışın çok düşük bir orada kalması defter değeri değişkeni açısından 2005 öncesi ve sonrası dönemde piyasa değeri üzerine etkisinde bir değişme olmadığı sonucunu göstermektedir.

Tüm modellerde açıklama gücünde artış görülürken defter değeri ve piyasa değeri değişkenlerinin kullanıldığı modelde bu artışın görülmemesi sebepleri üzerine odaklanacak olursa, öncelikle 2005-2009 dönemi Türkçe TMS’lerin incelenmesi gerekmektedir. İlgili dönemde standartlar içerisinde defter değerini etkileyen, gerçek durumunu yansıtması amacıyla oluşturulan düzenlemeler bulunmaktadır (Yeniden değerleme artışları/azalışları,

\footnotetext{
${ }^{6}$ Panel Düzeltilmiş Standart Hataları tahmincisi ile elde edilen tahmin sonuçları kullanılmıştır (Beck-Katz, 1995).
} 
gerçeğe uygun değer düzenlemeleri, vs.). Ancak ilgili dönem aralığında 6102 sayılı Türk Ticaret Kanunu'nun yürürlükte olmaması nedeniyle Standartlar Kanun yaptırımı taşımamaktadır (6102 TTK, yürürlük tarihi 14.02.2011 - 27846 nolu Resmi Gazate). Bu durum 3475 sayılı Vergi Usul Kanunu ile uyumsuz olan yeniden değerleme artışları/azalışları, gerçeğe uygun değer, vs. konularında halka açık şirketlerin defter değeri ile ilgili TMS uygulamalarına başlamamasına bir neden oluşturmuştur. Zira çalışma dönemi ham veri setinin incelenmesi sonucunda, 2005 öncesi dönemde enflasyon muhasebesi gereği Yeniden Değerleme Artışları hesap grubu işlem görmüşken; 2005-2011 döneminde bu hesabın çoğu firma için işlem görmediği ve sıfır bakiye ile raporlandığ 1 tespit edilmiştir. 2011 sonrasında işlem görmeye başlayan bu hesap grubu, az önce açıklanan durumun uygulamadaki kanıtı olarak gösterilebilmektedir. Bu durumda defter değeri değişkeni için, yatırımcılar açısından, 2005 öncesi ve sonrası dönemde standartlardan kaynaklanan bir değişim söz konusu değildir ve açıklama gücü bu nedenle hemen hemen aynı düzeyde kalmıştır. Defter değeri açısından elde edilen sonuçlar diğer bir yandan incelenecek olursa, standartlaştırılmış Ohlson modelinde açıklama gücünün 2005 öncesi ve sonrası dönem açsından yaklaşık olarak \%87 artış gösterdiği görülmüştür. $\mathrm{Bu}$ durum klasik Ohlson modelindeki sonuç ile çelişkili şekilde görünmesine rağmen, önemli bir bilgi içermektedir. Defter değeri değişkeninin, piyasa değeri değişkeninin bir dönem gecikmeli değeri ile standartlaştırılması ile oluşturulmuş modelin açıklama gücündeki değişim, yatırımcıların aslında defter değeri ile temsil edilen özkaynak kaleminin gerçek değerini piyasadan öğrenip fiyatlara yansıttığı görüşünü güçlendirmektedir. Bu gösterge, piyasada bir asimetrik bilgi durumunun mevcut olduğunun ve yatırımcıların aslında TMS ile açıklanması amaçlanan kaliteli bilgiye piyasa kaynakları yollardan ulaştığını göstermektedir.

Çalışmada yapılan analizler sonucunda, 2005 sonrası TMS/TFRS uygulamaları ile hazırlanan finansal tabloların, şirketlerin piyasa değerlerini açıklamada yerel mevzuattan daha iyi performans gösterdiği ifade edilebilmektedir. Bu durum, IASB amaçlarının Türkiye piyasasında büyük ölçüde oluştuğunu göstermektedir. 


\section{KAYNAKLAR}

Aygören Hakan (2007), "Yerel Mevzuat ve Uluslararası Finansal Raporlama Standartları (UFRS) Temelli Finansal Tabloların Hisse Senedi Fiyatlarını Açıklama Gücü: İstanbul Menkul Kıymetler Borsasın'da (İMKB) Bir Çalışma”, 11. Finans Sempozyumu Bildiri Kitab1.

Bartov, E.- Goldberg, S. R. - Kim, M. (2005), “Comparative Value Relevance Among German, US and International Accounting Standards: A German Stock Market Perspective”, Journal of Accounting Auditing \& Finance, 20(2), pp. 95-119.

Beck, N. - Katz, J.N. (1995), "What To Do (and Not To Do) with Time-Series Cross-Section Data.”, American Political Science Review, 89, pp. 634-47.

Beckman, J.- Brandes, C. - Eierle, B. (2007). “German Reporting Practices: An Analysis of Reconciliations from German Commercial Code to IFRS or US GAAP”, Advances in International Accounting, Volume 20, 25, pp. 253-294.

Breusch, T.S. - Pagan, A.R. (1980), “The Lagrange Multiplier Test and Its Applications to Model Specification in Econometrics”, Review of Economic Studies, 47, pp. 239-253.

Byard, D.- Li, Y.- Yu, Y. (2010), “The Effect of Mandatory IFRS Adoption on Financial Analysts’ Information Environment”, Journal of Accounting Research, Vol. 49, No. 1, pp. 69-96.

Callao, S.- Jarne, J. I. - La'inez, J. A. (2007), “Adoption of IFRS in Spain: Effect on The Comparability and Relevance of Financial Reporting”, Journal of International Accounting, Auditing and Taxation, 16, pp. 148-178.

Carrion-i-Silvestre, J.L.- del Barrio-Castro, T. - Lopez-Bazo, E. (2005), "Breaking the Panels. An Application to the GDP per Capita”, Econometrics Journal, 8, pp. 159-175.

Christensen, H. B-, Lee, E. - Walker, M. (2007), “Cross-sectional Variation in The Economic Consequences of International Accounting Harmonization: The Case of Mandatory IFRS Adoption in The UK”, The International Journal of Accounting, 42, pp. 341379.

Clarkson, P.- Hanna, D.- Richardson, G. D. - Thompson, R. (2011), “The Impact of IFRS Adoption on The Value Relevance of Book Value and Earnings”, Journal of Contemporary Accounting \& Economics, 7, pp. 1-17.

Delvaille, P.- Ebbers, G. - Saccon, C. (2005,. “International financial reporting convergence: evidence from three continental European countries”, Accounting in Europe, 2, pp. 137-164.

Eccher, E. A. - Healy, P. M. (2000), “The Role of International Accounting Standards in Transitional Economies: A Study of the People's Republic of China”, Social Science Research Network Electronic Paper Collection, http://papers.ssrn.com/paper.taf?abstract_id=233598, pp. 1-46. 
Filip, A. - Raffournier, B. (2010), “The Value Relevance of Earnings in a Transition Economy: The Case of Romania”, The International Journal of Accounting, 45, pp. 77-103.

Gjerde, O.- Knivsfla, K. - Saettem, F. (2008), “The Value-Relevance of Adopting IFRS: Evidence from 145 NGAAP Restatements”, Journal of International Accounting, Auditing and Taxation, Vol. 17, pp. 92-112.

Goodwin, J.- Ahmed, K. - Heaney, R. (2008), “The Effects of International Financial Reporting Standards on the Accounts and Accounting Quality of Australian Firms: A Retrospective Study”, Journal of Contemporary Accounting \& Economics, Vol 4, No 2, pp. 89-119.

Güloğlu, B. - İspir, S. (2009), "Yeni Gelişmeler Işığında Türkiye'de Satın Alma Gücü Paritesi Hipotezinin Panel Birim Kök Sınaması", içinde, "Makro Ekonomik Zaman Serileri Analizi, Eşbütünleşme ve Modelleme Yöntemleri’, DEU Yayınları, İzmir.

Harris, M. S. - Muller, K. A. (1999), “The Market Valuation of IAS Versus US-GAAP Accounting Measures Using form 20-F Reconciliations”, Journal of Accounting \& Economics, 26(1-3), pp. 285-312.

Hausman, J., (1978), Specification Tests in Econometrics, Econometrica, 46, pp. 1251-1271.

Horton, J. - Serafeim, G. (2006), "Market response to and the value relevance of reconciliation adjustments from UK GAAP to IFRS GAAP: First Evidence from the UK”, Review of Accounting Studies, 15, No. 4, pp. 725-751.

Horton, J. - Serafeim, G. (2010), "Market Reaction to and Valuation of IFRS Reconciliation Adjustments: First Evidence from The UK”, Review of Accounting Studies, 15, pp. 725-751

Hung, M. - Subramanyam, K. R. (2007), "Financial Statement Effects of Adopting International Accounting Standards: The Case of Germany”, Review of Accounting Studies, 12, pp. 623-657.

Iatridis, G. - Rouvolis, S. (2010). “The Post-Adoption Effects of The Implementation of International Financial Reporting Standards in Greece”, Journal of International Accounting, Auditing and Taxation, 19, pp. 55-65.

Jermakowicz, E. K. (2004), "Effects of Adoption of International Financial Reporting Standards in Belgium: The Evidence from BEL-20 Companies”, Accounting in Europe, 1, pp. 51-70.

Jermakowicz, E. K.- Gornik-Tomaszewski, S. (2006), "Implementing IFRS from the Perspective of EU Publicly Traded Companies”, Journal of International Accounting Auditing and Taxation, 15, pp. 170-196. 
Jermakowicz, E. K.- Prather-Kinsey, J. - Wulf, I. (2007), "The Value Relevance of Accounting Income Reported by DAX-30 German Companies", Journal of International Financial Management and Accounting, 18:3, pp. 151-191.

Kwiatkowski, D-, Phillips, P.C.B.- Schmidt, P. J. - Shin Y. (1992). "Testing the Null Hypothesis of Stationarity Against the Alternative of A Unit Root: How Sure are We That Economic Time Series Have A Unit Root”, Journal of Econometrics 54, pp. 15978.

Larson, R. K. - Street, D. L. (2004) "Convergence with IFRS in An Expanding Europe: Progress and Obstacles Identified by Large Accounting Firms' Survey”, Journal of International Accounting, Auditing and Taxation, 13, pp. 89-119.

Lin, Z. J. - Chen, F. (2005), "Value Relevance of International Accounting Standards Harmonization: Evidence from A- and B-Share Markets in China", Journal of International Accounting, Auditing and Taxation, 14, pp. 79-103.

Morais, A. I. - Curto, J. D. (2008), “Accounting Quality and The Adoption of IASB Standards - Portuguese Evidence”, Revista Contabilidade \& Finanças, V. 19, N. 48, pp. 103-111.

Niskanen, J.- Kinnunen, J. - Kasanen, E. (2000), “The Value Relevance of IAS Reconciliation Components: Empirical Evidence from Finland”, Journal of Accounting and Public Policy, 19, pp. 119-137.

Ohlson, J. A. (1995). "Earnings, Book Values, and Dividends in Equity Valuation”, Contemporary Accounting Research, Vol. 11, No. 2, pp. 661-687.

Oliveira, L.- Rodrigues, L. L. - Craig, R. (2010), "Intangible Assets and Value Relevance: Evidence from the Portuguese Stock Exchange”, The British Accounting Review, 42, pp. 241-252.

Ormrod, P. - Taylor, P. (2004), “The Impact of the Change to International Accounting Standards on Debt Covenants: A UK perspective”, Accounting in Europe, 1, pp. 7194.

Paananen, M. (2008), “The IFRS Adoption's Effect on Accounting Quality in Sweden”, Social Science Research Network Electronic Paper Collection, http://ssrn.com/abstract=1097659.

Palea, V. (2013), "Capital Market Effects of the IFRS Adoption for Separate Financial Statements: Evidence from the Italian Stock Market”, Working Paper Series, No. 09/2013, Università di Torino.

Pesaran, M. H. (2004), “General Diagnostic Tests for Cross Section Dependence in Panels", University of Cambridge, Faculty of Economics, Cambridge Working Papers in Economics No. 0435. 
Schadewitz, H. - Vieru, M. (2007), "How Markets Valuate and Response to IFRS Reconciliations Adjustments in Finland”, DOI: http://dx.doi.org/10.2139/ssrn.1005601.

Schiebel, A. (2006), "Value Relevance of German GAAP and IFRS Consolidated Financial Reporting: An Empirical Analysis on The Frankfurt Stock Exchange”, Social Science Research Network Electronic Paper Collection, http://ssrn.com/abstract=916103.

Suadiye, G. (2012), "Value Relevance of Book Value \& Earnings Under The Local GAAP and IFRS: Evidence from Turkey”, Ege Academic Review, 12-3, pp. 301-310.

Sultanoğlu, B. (2014), “UFRS'nin Borsa İstanbul'daki Şirketlerin Finansal Tabloları Üzerindeki Etkisi: Finansal Bilginin İhtiyaca Uygunluğu ve Finansal Tablolar Analizi” Başkent Üniversitesi, Sosyal Bilimler Enstitüsü, İşletme Anabilim Dalı, Yayımlanmamış doktora tezi, Ankara.

Taylor, M. - Sarno, L. (1998), “The Behaviour Of Real Exchange Rates During The PostBretton Woods Period”, Journal of International Economics, 46, pp. 281-312.

Tsalavoutas, I.- André, P. - Evans, L. (2012), "The Transition to IFRS and The Value Relevance of Financial Statements in Greece”, The British Accounting Review, 44, pp. 262-277.

Türel, A. (2009), “The Value Relevance of IFRS: The Case of Turkey”, Acta Universitatis Danubius Oeconomica, 5(1), pp. 119-128.

Uyar, U. (2015), “Finansal Raporlama Standartları'nın Piyasa Değerini Açıklama Gücü Üzerine Etkisi”, Pamukkale Üniversitesi, Sosyal Bilimler Enstitüsü, Yayımlanmamış doktora tezi, Denizli.

Weißenberger, B. E.- Stahl, A. B.- Vorstius, S. (2004), “Changing from German GAAP to IFRS or US GAAP: A survey of German companies”, Accounting in Europe, 1, pp. 169-189.

Wooldridge, J. M. (2002), Econometric Analysis of Cross Section and Panel Data, Cambridge, Ma: MIT Press.

Wooldridge, J. M. (2013), Introductory Econometrics: A Modern Approach, $5^{\text {th }}$ Edition, South-Western, Cengage Learning, USA. 
